\title{
INULIN OBTAINED FROM JERUSALEM ARTICHOKE USING MICROWAVE-ASSISTED EXTRACTION AND ITS METABOLIC INFLUENCE
}

\author{
Manuel DRUGULESCU ${ }^{1 *}$, Cristina Elena DINU-PIRVU², Narcisa BABEANU ${ }^{1}$ \\ ${ }^{1}$ University of Agronomic Sciences and Veterinary Medicine of Bucharest, Bucharest, Romania \\ 2 Department of Physical and Colloidal Chemistry, Faculty of Pharmacy, "Carol Davila" University of \\ Medicine and Pharmacy, Bucharest, Romania
}

\author{
Received 07 Oct 2021, Accepted 18 Nov 2021 \\ https://doi.org/10.31688/ABMU.2021.56.4.12
}

\begin{abstract}
Introduction. Inulin has high potential as a supplement for food, pharmaceutical and medical use and raised an increased interest in obtaining high-quality products.

The objective of the study was to evaluate the physiological impact of the administration of inulin obtained by microwave hydrodiffusion and gravity (MHG).

Materials and methods. Helianthus tuberosus was used as a raw material from commercial sources. The inulin was extracted using MHG, followed by separation. The extraction method has been optimized by surface response methodology (SRM). The obtained inulin was administered to laboratory animals. The influence of the administration of standard inulin (INS), inulin obtained by MHG (INE) and inulin obtained by MHG in combination with quercetin $(\mathrm{INE}+\mathrm{Q})$ was evaluated, for 12 days, on the variation of weight and blood parameters such as blood sugar, cholesterol and triglycerides.

Results. Inulin was obtained at optimal values $\left(74.74{ }^{\circ} \mathrm{C}\right.$ and $\left.15.55 \mathrm{~min}\right)$; the yield was $72.98 \%$. The
\end{abstract}

\section{RéSUmé}

Inuline obtenue à partir de l'artichaut de Jérusalem par extraction assistée au micro-ondes et son influence métabolique

Introduction. L'inuline a un fort potentiel en tant que complément pour l'alimentation, l'industrie pharmaceutique et l'utilisation médicale et constitue un intérêt accru pour l'obtention de produits de haute qualité. L'objectif de l'étude était d'étudier l'impact physiologique de l'administration d'inuline obtenue par hydro diffusion micro-ondes et gravité (HMG).

Matériaux et méthodes. Helianthus tuberosus a été utilisé comme matière première à partir de sources commerciales. L'inuline a été extraite à l'aide de HMG, suivie d'une séparation. La méthode d'extraction a été optimisée par méthodologie de réponse de surface (SRM). L'inuline obtenue a été administrée à des animaux de laboratoire. L'influence de l'administration d'inuline standard (INS), d'inuline obtenue par HMG (INE) et d'inuline obtenue par HMG en association avec la quercétine $(\mathrm{INE}+\mathrm{Q})$ a été évaluée, pendant 12 
statistical analysis revealed that on the first day of treatment there are statistically significant differences only between the groups treated with INS and INE. On the third day of treatment, significant differences occur only when comparing the weights recorded in the batches treated with INS and INE+Q. In the following days of treatment $\left(5^{\text {th }}, 7^{\text {th }}\right.$, and $\left.9^{\text {th }}\right)$ there were statistically significant differences only between the groups treated with INS and INE. Even though there are significant differences between the two groups, all data fall within the normal range. On the $12^{\text {th }}$ day of treatment, the results obtained were considered statistically insignificant.

Conclusions. The use of inulin obtained by innovative MHG proved to have positive effects on laboratory animals.

Keywords: inulin, microwave, extraction, modelling, metabolism.

Abbreviations: $\mathrm{MHG}$ - microwave hydrodiffusion and gravity, SRM - surface response methodology, INS - standard inulin, INE - inulin obtained by $\mathrm{MHG}, \mathrm{INE}+\mathrm{Q}$ - inulin obtained by MHG in combination with quercetin, SCFA - short-chain fatty acids, $\mathrm{kg} / \mathrm{bw}$ - kilograms per body weight, $\mathrm{PD}$ - polymerization degree.

\section{INTRODUCTION}

\section{Inulin}

Inulin is a substance with a high economic potential and obtaining it from Jerusalem artichoke (Helianthus tuberosus), a raw material relatively cheap, is important. The improvement of methods of obtaining it is a goal that must be continuously pursued to reach the potential offered by this plant. Jerusalem artichoke is a plant traditionally cultivated and has been used in human food for a very long time, being considered one of the oldest cultivated plants.

In plants with a high fructan content, inulin is found in vacuoles alongside fructose molecules and a small proportion of glucose molecules ${ }^{1}$. The accumulation of fructans in these vacuoles is the consequence of the intense photosynthetic activity that jours, sur la variation du poids et des paramètres sanguins: la glycémie, le cholestérol et les triglycérides.

Résultats. L'inuline a été obtenue à des valeurs optimales $\left(74,74{ }^{\circ} \mathrm{C}\right.$ et $\left.15,55 \mathrm{~min}\right)$; le rendement était de $72,98 \%$. D'après l'analyse statistique, il est observé que le premier jour de traitement, il n'y a de différences statistiquement significatives qu'entre les groupes traités par INS et INE. Le troisième jour de traitement, des différences significatives ne se produisent que lors de la comparaison des poids enregistrés dans les lots traités avec INS et INE + Q. Dans les jours de traitement suivants $(5 \mathrm{e}, 7 \mathrm{e}$ et $9 \mathrm{e})$ il y avait des différences statistiquement significatives qu'entre les groupes traités par INS et INE. Même s'il existe des différences significatives entre les deux lots, toutes les données se situent dans la plage normale. Le 12e jour de traitement, les résultats obtenus ont été considérés comme statistiquement insignifiants.

Conclusions. L'utilisation de l'inuline obtenue par HMG innovant a prouvé les effets positifs sur les animaux de laboratoire.

Mots-clés: inuline, micro-ondes, extraction, modélisation, métabolisme.

takes place in chloroplasts where a high amount of carbon is generated, which is then transferred into the cytoplasm, leading to sucrose synthesis; subsequently, sucrose is pumped to the deposit vacuoles, where it is transformed into inulin by the action of fructosyltransferase.

\section{Sources}

Natural sources of fructans are found in many plants of mono and dicotyledonous families, such as those of the Liliaceae, Amarylidaceae, Gramineae and Compositae families (over 25,000 species) $)^{2}$. They produce fructans in significant quantities, stored in the roots and rhizomes as a reserve substance, but it is also found in some species of bacteria ${ }^{3}$. Speaking specifically about inulins, this class of fructans is common and prevalent in the Compositae family (Table 1$)^{4}$.

Table 1. Inulin content in Dahlia, Jerusalem artichoke, and Chicory ${ }^{5}$

\begin{tabular}{cccc}
\hline & Dhalia & $\begin{array}{c}\text { Jerusalem arti- } \\
\text { choke }\end{array}$ & Chicory \\
\hline Roots or tubers [t/ ha] (average) & 25 & 42 & 43,5 \\
\hline Dry matter [\%] (average) & 18 & 22 & 22,5 \\
\hline Inulin [\%] (average) & 11 & 16 & 16,5 \\
\hline The degree of polymerization of inulin (average) & $13-20$ & $6-10$ & $10-14$ \\
\hline
\end{tabular}


Helianthus tuberosus L. or Jerusalem artichoke is a plant that is among the oldest plants to be grown in North America, which is also considered to be the region of origin from which it spread. One of the earliest mentions of an author in Europe of Jerusalem artichoke is that of Champlain, who described in 1605 (published in 1613) the cultivation of Jerusalem artichoke by the North American natives. It is a flowering plant of the family Asteraceae, native to cold areas with a high content of inulin (14-19\%) in its tubers. The high extraction yield (98\%) of inulin was obtained from Jerusalem artichoke under the conditions in which the tubers were processed and turned into dry powder ${ }^{6}$; these inulins present themselves as medium chain $\left(\mathrm{PD}_{\max }<40\right)^{7}$.

\section{Extraction of inulin}

The microwave extraction method has several variants of application. Of these, the microwave hydrodiffusion and gravity (MHG) extraction technique can be considered to be a "green" technology because it does not use any solvents (water or other solvents), the compounds concerned being extracted with the structural water existing in the fresh plant material and are collected in a vessel due to gravity, at atmospheric pressure ${ }^{8}$. The technique has been designed for both laboratory and industrial applications. The physical phenomenon that occurs in this technique is hydrodiffusion, as a result of microwave heating, through which the extract formed from the water contained in the fresh plant material together with the targeted compounds is released into the extracellular and extra-tissue environment ${ }^{9}$.

\section{Metabolic effects with medical impact}

Dietary supplementation with inulin-based products positively influences the absorption of calcium and magnesium ${ }^{10}$. Some studies have shown that inulin favours calcium absorption, bone mineral density and can reduce the risk of osteoporosis ${ }^{11}$. It has been shown that in inulin-fed mice, the absorption of calcium and magnesium was much higher than that of control mice. This phenomenon was due to the osmotic character of inulin, which transfers water to the large intestine, allowing calcium to become more soluble ${ }^{12}$, and suggested that the effect of inulin fermentation is important for calcium absorption. In humans, however, inulin only improved the absorption of calcium, and not of iron and zinc ${ }^{13}$. Another phenomenon that intervenes positively in the absorption of calcium and magnesium in the colon is the decrease in $\mathrm{pH}$ that results in the increase in the level of short-chain fatty acids ${ }^{14}$.

Inulin has been shown to decrease the risk of cancer, using various experimental models in a trial ${ }^{15}$.
In studies on mice, it has been identified that the effect that supports this action is achieved by the combined action of increasing the beneficial intestinal microflora (due to the rapid fermentation of inulin-type fructan) and implicitly by increasing the microbial metabolic rate. A decrease in the risk of carcinogenesis was observed in the case of prior supplementation of the diet with inulin ${ }^{16}$.

Butyrate, a short-chain fatty acid, a product of inulin fermentation, is metabolized in the epithelium of the colon and due to its antitumour action plays an important role in lowering the risk of developing colon cancer; the presence of butyrate induces the selective apoptosis of cancer cells by acetylation of histone proteins from the nucleus of cells ${ }^{14}$.

Also, in a study in mice it was observed that the development of breast cancer was inhibited by the inulin introduction into the diet, which led to the conclusion that the regular and prolonged consumption of inulin-type fructans also achieves a systemic cancer prevention effect ${ }^{17}$. The antitumour effect of regular consumption of inulin-type fructans is also correlated with the production in the large intestine of short-chain fatty acids SCFA (the main fermentation product of fructans) - mainly the production of butyrate - which also stimulates the immune system at local level ${ }^{18}$.

The modulating effect of inulin consumption on the immune system associated with the intestinal digestive system was also observed; data from research show impact of supplementation of inulin in animal and human food; results and conclusions highlight that immune cells are primarily activated by inulins. ${ }^{19}$.

It has also been observed that by increasing the level of short-chain fatty acids in the colon because of the fermentation of inulins, the production of proglucagon is stimulated, a precursor of some peptides with an endocrine role, that modulates the functions of the pancreas, and appetite is stimulated ${ }^{20}$.

The effects of treatment with inulin obtained by extraction using the MHG are presented in this paper. This treatment was applied to 8 groups of laboratory animals for 12 days. Another objective of our study was to compare the effects of treatment with inulin obtained by extraction (inulin obtained by MHG in combination with quercetin $(\mathrm{INE}+\mathrm{Q})$, or without quercetin - INE) with standard inulin (INS) on laboratory tests following the administration of these 3 variants of inulin.

The objective OF THE StUdy was the evaluation of the physiological impact of the administration of inulin obtained by MHG. The first step was the obtaining of inulin from Helianthus tuberosus by an 
innovative extraction technology without any type of solvent, the second step was the optimization of the process and the last one was the evaluation of the effect of administration of 3 types of inulin in laboratory animals.

\section{Materials and Methods}

\section{Purchase and preparation}

Jerusalem artichoke tubers were purchased; the variety, provenance and time of collection have not been indicated on presentation of the product. Jerusalem artichokes are presented with an irregular surface, light brown in colour, having a round, spheroidal shape. Jerusalem artichoke tubers were cleaned of soil residues, washed, and their dimensions, weight, and humidity were measured.

The next step was to peel the tubers, to minimize the concentration of impurities in the obtained extracts, followed by scraping them on a grater, obtaining small slices of $1-2 \mathrm{~mm}$ thickness and between $1.5-2 \mathrm{~cm}$ length.

\section{Extraction}

The equipment used was ETHOS X (Milestone Systems A/S) which consists of an enclosure that isolates itself from the working environment during operation, a glass vessel with a run-in lid and connections at the top (on the lid) or at the bottom for connection to the cooling system (refrigerant); the system has a measurement and control system for microwave power, temperature, and extraction time.

The solution absorbance measurement was made with SPECORD 210 PLUS double-beam spectrometer (Analytic Jena $\left.{ }^{\circledR}\right)$, having the wavelength range between $185-1,200 \mathrm{~nm}$, spectral resolution between 2.3-2.5 and spectral bandwidth of $0.2 / 0.5 / 1 / 2 / 4$ $\mathrm{nm}$. All chemicals and reagents used were analytical grade reagents. Substances used: pure ethanol, sodium periodate $\left(\mathrm{NaIO}_{4}\right) 10 \mathrm{mmol} / \mathrm{L}$, citrate buffer solution $20 \mathrm{mmol} / \mathrm{L}$, potassium iodide (KI) $100 \mathrm{mmol} / \mathrm{L}, \mathrm{HCl}$ $0.2 \mathrm{~mol} / \mathrm{L}, \mathrm{NaOH} 0.2 \mathrm{mmol} / \mathrm{L}$, standard fructose.

\section{Separation of inulin from the extract}

The separation of inulin was carried out by centrifugation at 3,300 rpm for $15 \mathrm{~min}$, according to the method described ${ }^{21}$. The falcon tubes with the obtained extracts were homogenized at the vortex, then transferred to the centrifuge tubes and weighed before their introduction into the centrifuge. After centrifugation, the supernatant was filtered through the $3 \mathrm{~mm}$ Whatman filter paper. The filtrate obtained was weighed and then concentrated at rotavapor at $45^{\circ} \mathrm{C}$ and finally the solution obtained was brought, in the volumetric flask, to a volume of $25 \mathrm{~mL}$. Part of the resulting solution was purified and dried to determine the yield and the remaining volume was used for the spectrophotometric determination of inulin.

\section{Purification of inulin from the filtrate}

The purification of inulin was carried out according to the method described by Yuoh $\mathrm{Ku}^{22}$ modified by precipitation with pure ethanol. Precipitation in ethanol is favoured by a high ethanol-extract ratio, as well as low temperatures. A $5 \mathrm{~mL}$ volume of the extract was taken after separation to which $20 \mathrm{~mL}$ of ethanol was added to ensure optimum precipitation, then homogenized at the vortex, and subsequently kept at $4{ }^{\circ} \mathrm{C}$ for $24 \mathrm{~h}$ to intensify precipitation. After this time interval, the samples were centrifuged at $2500 \mathrm{rpm}$ for $10 \mathrm{~min}$, the ethanol was separated, and the precipitate was taken into a Berzelius beaker; $10 \mathrm{~mL}$ of ethanol was added to the solvent and then the samples were again centrifuged at $2500 \mathrm{rpm}$ for $10 \mathrm{~min}$. In the end, the ethanol was separated again, the resulting precipitate was added to the Berzelius beaker at the previously obtained precipitate, it was placed in the oven at $110^{\circ} \mathrm{C}$ for $75 \mathrm{~min}$, to remove the remaining ethanol in the precipitate. After removing them from the oven, the samples were weighed again $\left(m_{\mathrm{p}}\right)$.

\section{Spectrophotometric determination of inulin}

The spectrophotometric determination of inulin was performed according to the method proposed by Araya Saengkanuk ${ }^{23}$. The calculation of the concentration of inulin was carried out by the difference between the concentration of total fructose and the concentration of free fructose in the test sample; for the determination of total fructose, an acid hydrolysis of the sample was performed.

\section{Statistical analysis}

The statistical analysis of the experimental data obtained was performed using the XLSTAT (Addinsoft) v. 2021.3.1 and MINITAB v. 20.3 (Minitab LLC) programs.

\section{Materials and methods for the study of inulin treatment effects}

Laboratory animals weighing $210 \pm 10 \mathrm{~g}$ purchased from the University of Medicine and Pharmacy "Carol Davila" Animal Base, Bucharest, Romania, were used. The animals were kept in cages with ventilation in constant temperature and humidity conditions. Food was provided twice a day, and water ad libitum. The animals were allowed to settle in for 48 hours before the experiment.

For the study, $40 \mathrm{Wistar}$ rats were needed (for variation of body weight, biochemistry tests and 


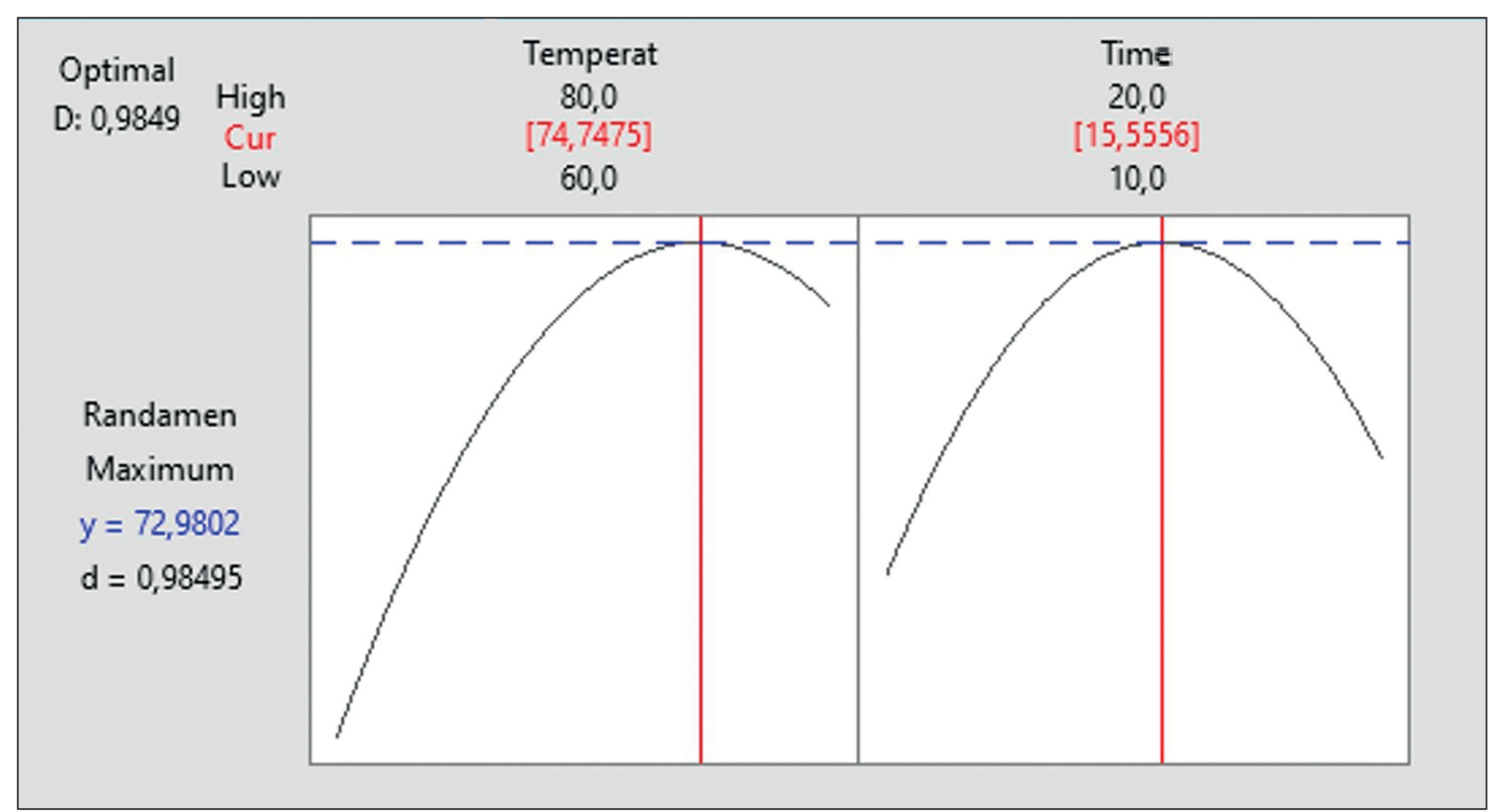

Fig. 1. Optimization of parameters using the SRM model

better accuracy of haematology tests) and 40 mice of Albino Swiss (for variation of body weight, biochemistry analysis).

To the selected laboratory animals, inulin from several sources: INS - inulin obtained by chemical synthesis, INE - inulin obtained by extraction process, INE+Q - inulin obtained by extraction process in combination with quercetin, was administered.

The laboratory animals used in the study were distributed in 4 groups of 10 rats weighing $290 \pm 10 \mathrm{~g}$, as follows:

- Group 1 - control treated p.o. with saline at a dose of $5 \mathrm{~mL} /$ kilograms per body weight $(\mathrm{kg} / \mathrm{bw})$.

- Group 2 - treated p.o. with INS in a dose of $100 \mathrm{mg} / \mathrm{kg} / \mathrm{bw}$.

- Group 3 - treated p.o. with INE at a dose of $100 \mathrm{mg} / \mathrm{kg} / \mathrm{bw}$.

- Group 4 - treated with INE+Q in doses of $100 \mathrm{mg} / \mathrm{kg} / \mathrm{bw}$.

The animals were monitored daily in terms of behaviour and general condition of the fur. On the last day of administration, 3 hours after treatment, the animals were anesthetized with ethyl ether and were slaughtered to collect blood samples and organs for histopathological examination.

\section{Biochemistry analysis}

The blood samples were allowed to clot at room temperature. The plasma was harvested after centrifugation at $3500 \mathrm{rpm}$ for 10 minutes. For biochemistry analyses, an ACCENT 300 - CORMAY (Cormay, Poland) with specific reagents was used to determine blood glucose, cholesterol concentration and triglycerides.

The following biochemical parameters were determined for each of the 4 groups of Wistar rats, as well as for the Albino Swiss groups of mice: glucose, total cholesterol, and triglycerides.

\section{Results}

\section{Optimizing the response}

By optimizing the quadratic model obtained with the experimental values of the extraction yields, the dependence of the efficiency on each parameter that intervenes in the process was identified and the optimal values were found (Figure 1). The optimum value of the yield $(72.98 \%)$ for temperature $=74.74^{\circ} \mathrm{C}$, for time $=15.55 \mathrm{~min}$.

\section{The mathematical model}

The equation describing the mathematical model is shown below (in uncoded units):

$$
\begin{gathered}
Y=-130,3+4,439 X_{1}+4,839 X_{2}-0,02887 X_{1}^{2}- \\
-0,1360 X_{2}^{2}-0,00827 X_{1} X_{2}
\end{gathered}
$$

For statistical analysis, experimental data, and estimated data, obtained from the mathematical model, equation (1), are used at points defined by the experimental plan (Table 2).

The test result confirms that standard deviations cannot be considered to differ in materiality level 0.05 . The linearity between the two sets of values 
Inulin obtained from Jerusalem artichoke using microwave-assisted extraction and its... - DRUGULESCU et al

Table 2. Primary statistics for the experimentally obtained yield vs. the one obtained by applying the mathematical model

\begin{tabular}{ccccccccc}
\hline Yield & N & Average & StDev & Variance & CoefVar & Min & Median & Max \\
\hline Experimental & 18 & 68,964 & 3,491 & 12,189 & 5,06 & 61,738 & 69,911 & 73,152 \\
\hline Model, equation (2) & 18 & 68,776 & 3,601 & 12,970 & 5,24 & 61,936 & 69,200 & 72,269 \\
\hline
\end{tabular}

Legend: StDev - standard deviation; CoefVar - coefficient of variance

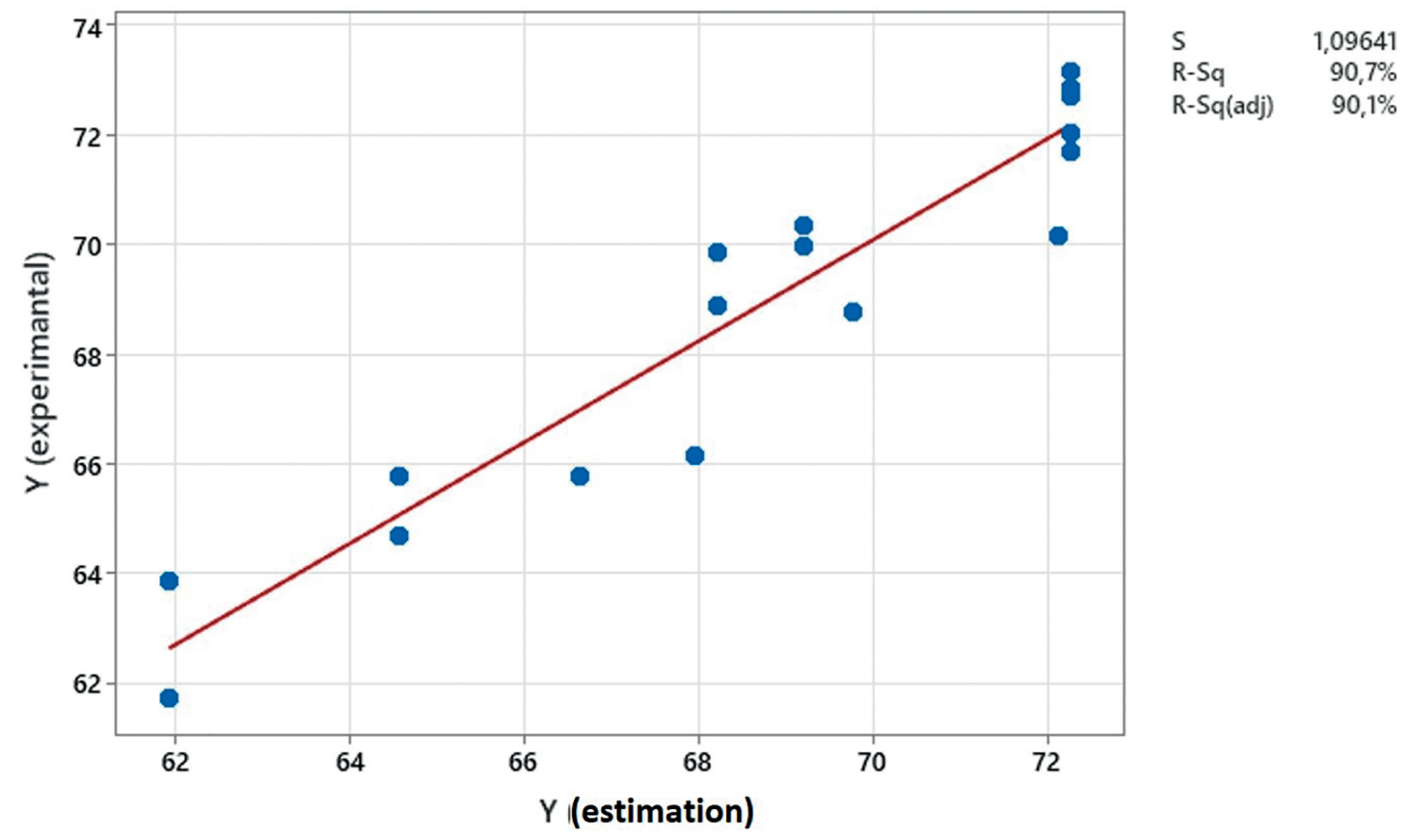

Fig. 2. Graphical representation of linear interpolation for the two sets of values

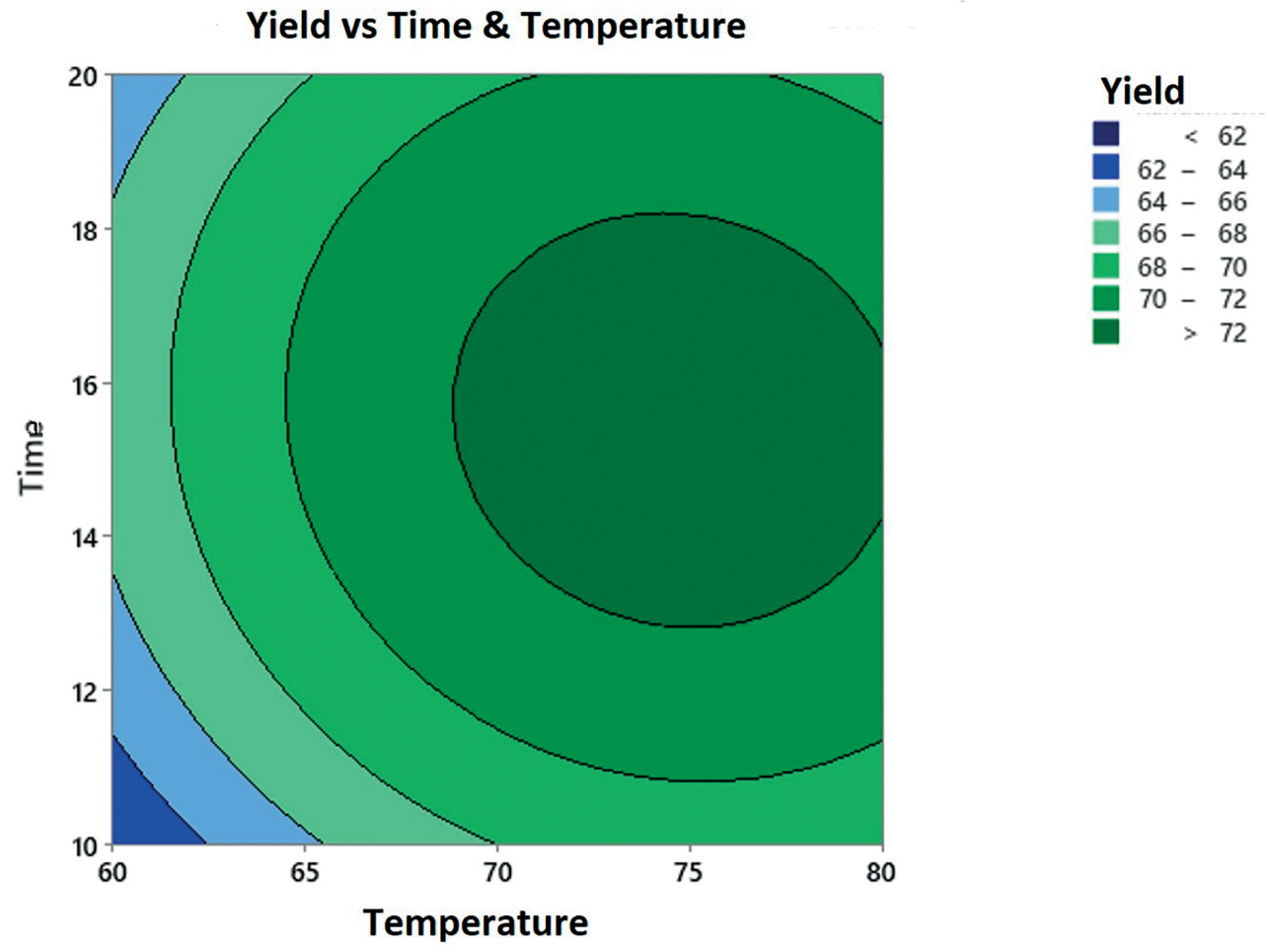

Fig. 3. Yield contour area as a function of temperature and time 
Table 3. Variation in body weight in Wistar rats (control/ INS/ INE/ INE + Q) from the $1^{\text {st }}$ to the $12^{\text {th }}$ day.

\begin{tabular}{cccccc}
\hline $\begin{array}{c}\text { Average } \\
\text { SD }\end{array}$ & Control & INS & INE & INE+Q & ANOVA \\
\hline Day 1 & $299.6 \pm 29.04$ & $328.75 \pm 18.50$ & $291.5 \pm 22.82$ & $304.5 \pm 25.92$ & $\mathrm{P}=0.0297$ \\
\hline Day 3 & $302.14 \pm 28.50$ & $333 \pm 16.55$ & $295.625 \pm 24.00$ & $305.625 \pm 27.75$ & $\mathrm{P}=0.0002$ \\
\hline Day 5 & $305.43 \pm 27.84$ & $334.625 \pm 17.69$ & $296.375 \pm 23.13$ & $305.5 \pm 26.90$ & $\mathrm{P}=0.0212$ \\
\hline Day 7 & $312.29 \pm 29.00$ & $339.5 \pm 18.59$ & $300.875 \pm 23.82$ & $310.125 \pm 28.35$ & $\mathrm{P}=0.0292$ \\
\hline Day 9 & $313.57 \pm 29.08$ & $340.75 \pm 19.75$ & $302.375 \pm 23.08$ & $310.625 \pm 28.36$ & $\mathrm{P}=0.032$ \\
\hline Day 12 & $296.29 \pm 29.58$ & $316.875 \pm 24.25$ & $286.875 \pm 21.95$ & $295.75 \pm 27.21$ & $\mathrm{P}=0.1465$ \\
\hline
\end{tabular}

Legend: INS = inulin obtained by chemical synthesis; INE = inulin obtained through the biotechnological process; INE+Q = inulin obtained by biotechnological process in combination with quercetin; SD =standard deviation

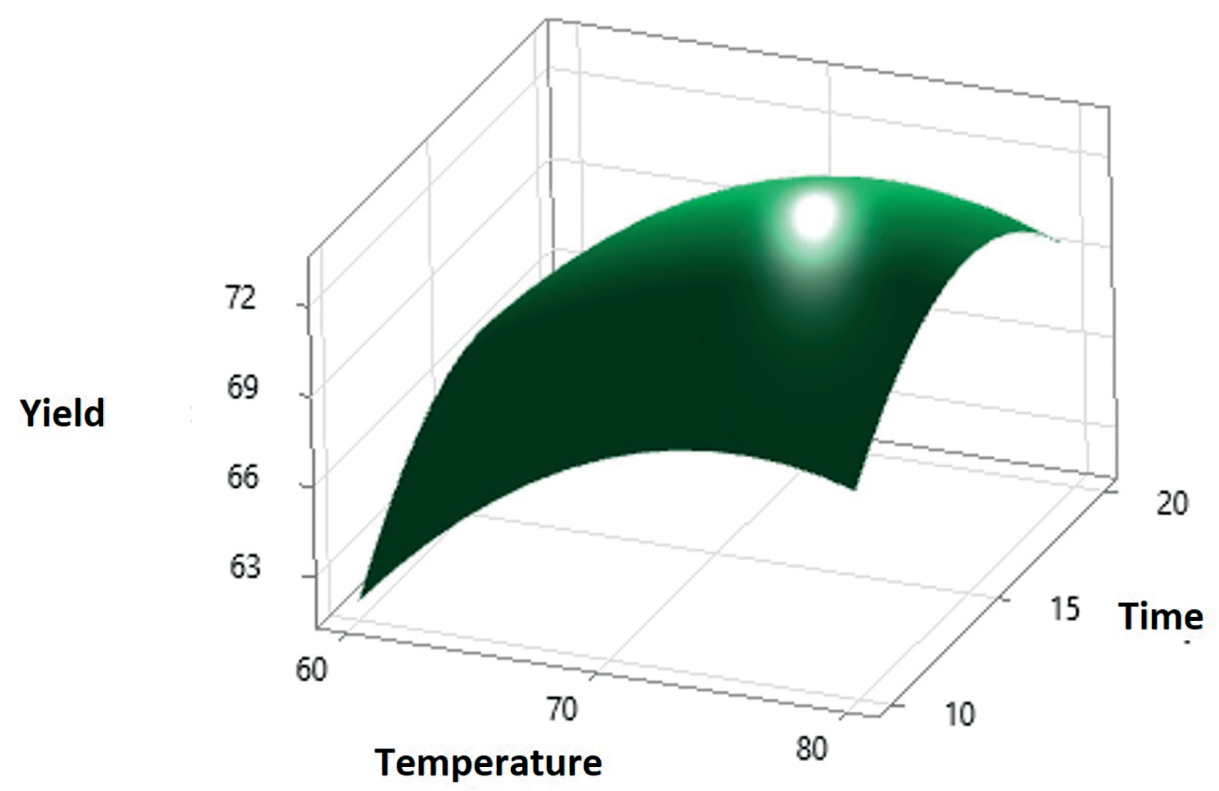

Fig. 4. Graph of the response area for yield (Y) as a function of temperature and time

(experimental, estimated) for the ultrasonic extraction yield of inulin $i$. also evidenced by the value $\mathrm{R}^{2}=$ 90.1\%; thus, the linear interpolation verified the linearity of experimental values in relation to the values obtained by modelling (Figure 2).

\section{Analysis and graphic interpretation of the model}

The graphical representation of the contour lines (Figure 3) and graph of the response area (Figure 4) highlights the behaviour of the parameters and the type of response surface they generate by applying the model. For the variation of the yield as a function of temperature and time, the response surface shows an optimum (temperature $74.74^{\circ} \mathrm{C}$, for time $15.55 \mathrm{~min}$ ) which is found at the values indicated by the mathematical model obtained (shown in Figure 1).

\section{Variation in body weight following treatment (INE, INE+Q) compared to INS}

In this experimental data set, the effect on the weight of Wistar rats in groups 1, 2, 3 and 4 was studied and analysed, following treatment with INS, INE administered alone or INE+Q, compared to laboratory animals to whom inulin was not administered.

\section{Statistical interpretation of data}

There is no significant difference in the weight variation of the laboratory animals to whom inulin has been administered (INE, INE+Q) from the control group; to increase the weight of the control group, higher than the other groups, one possible explanation is the increase in the overall metabolism, a phenomenon which is also indicated by the literature ${ }^{24}$.

In Figure 5, Figure 6 and Table 3 we presented the comparative body variation between the groups under study. From the statistical analysis of the data, it is observed that on the first day of treatment there are statistically significant differences only between the groups treated with INS and INE. On the third day of treatment, significant differences occur only when comparing the weights recorded in the groups 


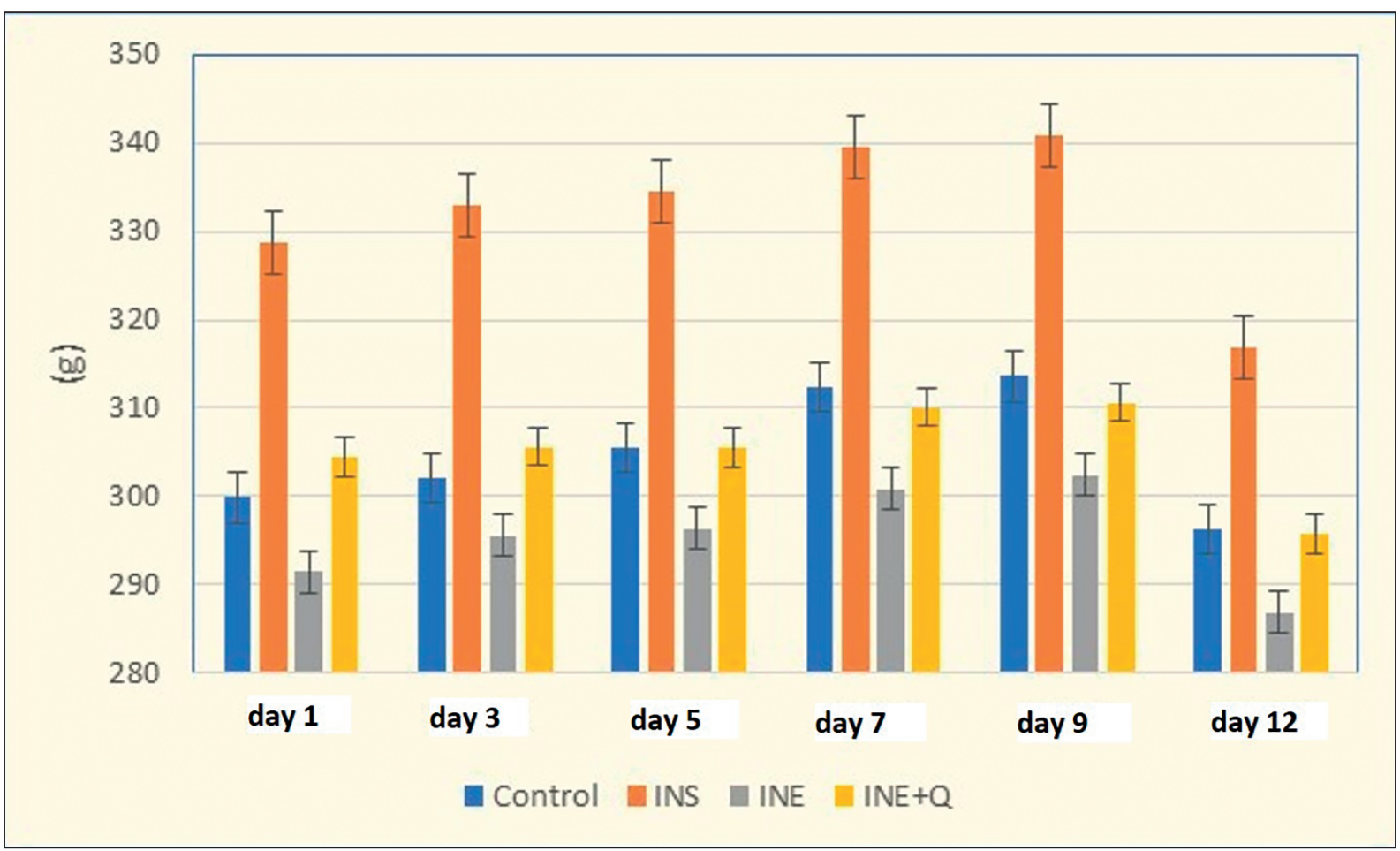

Fig. 5. Body weight variation in Wistar rats (control/ INS/ INE/ INE + Q)

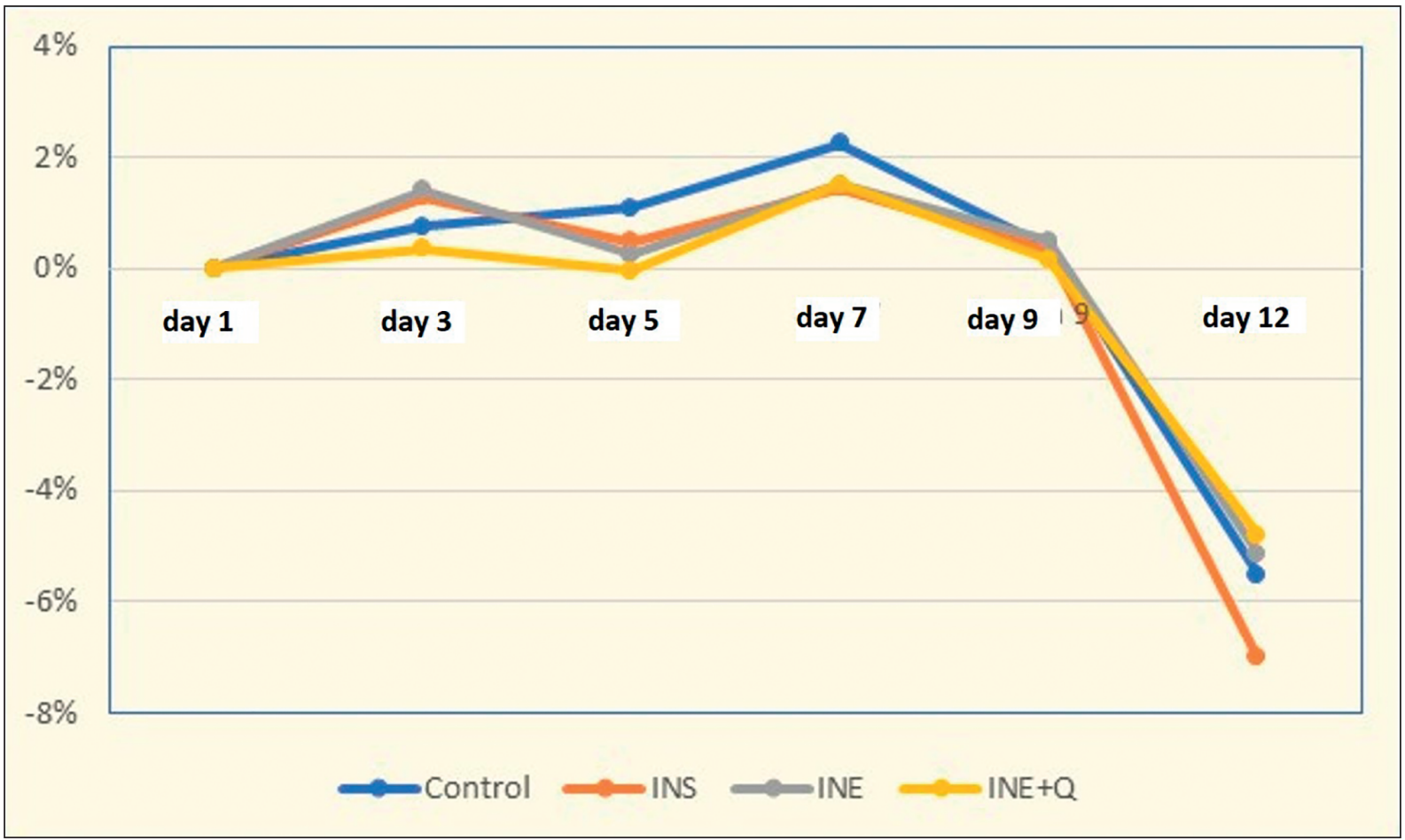

Fig. 6. Variation in body weight expressed as a percentage of Wistar rats (control/ INS/ INE/ INE + Q) compared to the first day of treatment over a 12-day administration period

treated with INS and INE+Q, and for the Control and INS groups there were high significant differences. In the following days of treatment $\left(5^{\text {th }}, 7^{\text {th }}\right.$, and $9^{\text {th }}$ day), there were statistically significant differences only between the groups treated with INS and INE. Even though there are significant differences between the two groups, all data fall within the normal range. In the $12^{\text {th }}$ day of treatment, the results obtained were considered statistically insignificant. 
Table 4. Statistical significance after comparison of body weight in Wistar rats (control/ INS/ INE/ INE + Q), applying the Bonferroni multiple comparison test

\begin{tabular}{|c|c|c|c|c|}
\hline Bonferroni multiple comparison tests & Average & $\mathrm{t}$ & P-value & Confidence interval \\
\hline \multicolumn{5}{|l|}{ Day 1} \\
\hline Control vs. INS & -28.9 & 2.31 & $P>0.05$ & $-64.5-6.75$ \\
\hline Control vs. INE & 8.36 & 0.667 & $P>0.05$ & $-27.3-44.0$ \\
\hline Control vs. INE+Q & -4.64 & 0.371 & $P>0.05$ & $-40.3-31.0$ \\
\hline INS vs. INE & 37.3 & 3.08 & $\mathrm{P}<0.05$ & $2.81-71.7$ \\
\hline INS vs. INE+Q & 24.3 & 2.00 & $P>0.05$ & $-10.2-58.7$ \\
\hline INE vs. INE+Q & -13.0 & 1.07 & $P>0.05$ & $-47.4-21.4$ \\
\hline \multicolumn{5}{|l|}{ Day 3} \\
\hline Control vs. INS & -29.88 & 3.466 & $\mathrm{P}<0.01$ & $-53.42-6.326$ \\
\hline Control vs. INE & 7.438 & 0.8628 & $P>0.05$ & $-16.11-30.99$ \\
\hline Control vs. INE+Q & -4.063 & 0.4713 & $P>0.05$ & $-27.61-19.49$ \\
\hline INS vs. INE & 37.31 & 4.480 & $\mathrm{P}<0.001$ & $14.56-60.06$ \\
\hline INS vs. INE+Q & 25.81 & 3.099 & $\mathrm{P}<0.05$ & $3.062-48.56$ \\
\hline INE vs. INE+Q & -11.50 & 1.381 & $P>0.05$ & $-34.25-11.25$ \\
\hline \multicolumn{5}{|l|}{ Day 5} \\
\hline Control vs. INS & -29.2 & 2.34 & $P>0.05$ & $-64.7-6.28$ \\
\hline Control vs. INE & 9.05 & 0.727 & $P>0.05$ & $-26.4-44.5$ \\
\hline Control vs. INE+Q & -0.0714 & 0.00573 & $P>0.05$ & $-35.5-35.4$ \\
\hline INS vs. INE & 38.3 & 3.18 & $\mathrm{P}<0.05$ & $3.98-72.5$ \\
\hline INS vs. INE+Q & 29.1 & 2.42 & $P>0.05$ & $-5.14-63.4$ \\
\hline INE vs. INE+Q & -9.13 & 0.758 & $P>0.05$ & $-43.4-25.1$ \\
\hline \multicolumn{5}{|l|}{ Day 7} \\
\hline Control vs. INS & -27.2 & 2.09 & $P>0.05$ & $-64.3-9.83$ \\
\hline Control vs. INE & 11.4 & 0.877 & $P>0.05$ & $-25.6-48.5$ \\
\hline Control vs. INE+Q & 2.16 & 0.166 & $P>0.05$ & $-34.9-39.2$ \\
\hline INS vs. INE & 38.6 & 3.07 & $\mathrm{P}<0.05$ & $2.84-74.4$ \\
\hline INS vs. INE+Q & 29.4 & 2.34 & $P>0.05$ & $-6.41-65.2$ \\
\hline INE vs. INE+Q & -9.25 & 0.736 & $P>0.05$ & $-45.0-26.5$ \\
\hline \multicolumn{5}{|l|}{ Day 9} \\
\hline Control vs. INS & -27.2 & 2.07 & $P>0.05$ & $-64.6-10.2$ \\
\hline Control vs. INE & 11.2 & 0.852 & $P>0.05$ & $-26.2-48.6$ \\
\hline Control vs. INE+Q & 2.95 & 0.224 & $P>0.05$ & $-34.5-40.3$ \\
\hline INS vs. INE & 38.4 & 3.02 & $\mathrm{P}<0.05$ & $2.24-74.5$ \\
\hline INS vs. INE+Q & 30.1 & 2.37 & $P>0.05$ & $-6.01-66.3$ \\
\hline INE vs. INE+Q & -8.25 & 0.650 & $P>0.05$ & $-44.4-27.9$ \\
\hline \multicolumn{5}{|l|}{ Day 12} \\
\hline Control vs. INS & -20.6 & 1.54 & $P>0.05$ & $-58.6-17.4$ \\
\hline Control vs. INE & 9.41 & 0.706 & $\mathrm{P}>0.05$ & $-28.6-47.4$ \\
\hline Control vs. INE+Q & 0.536 & 0.0402 & $P>0.05$ & $-37.4-38.5$ \\
\hline INS vs. INE & 30.0 & 2.33 & $P>0.05$ & $-6.67-66.7$ \\
\hline INS vs. INE+Q & 21.1 & 1.64 & $P>0.05$ & $-15.5-57.8$ \\
\hline INE vs. INE+Q & -8.88 & 0.689 & $P>0.05$ & $-45.5-27.8$ \\
\hline
\end{tabular}




\section{Discussion}

From the statistical analysis of the data, it is observed that the obtained results are considered statistically insignificant.

The normal values of cholesterol are 120 . $200 \mathrm{mg} / \mathrm{dL}$. Compared to the control group, the other three groups showed increases above the normal plasma cholesterol value, which proves that the INS and INE had an increasing effect on cholesterol concentration, a result that was also found in the literature data ${ }^{25}$.

Plasma triglycerides have normal values between $50-150 \mathrm{mg} / \mathrm{dL}$. In the experiment, the results showed that the administration of the three substances did not have a negative effect on triglycerides metabolism. Their values were within the normal range, even if in the case of the INE - treated group the triglycerides values were higher than in the other groups. Similar data have been indicated by the literature ${ }^{26}$.

The normal value of fasting blood glucose is $70-120 \mathrm{mg} / \mathrm{dL}$. The results of the study led to the conclusion that the substances administered had an almost hypoglycaemic effect on the animals. It was observed only in the INE+Q group once it increases above the value of $70 \mathrm{mg} / \mathrm{dL}$, which shows that the association of the two substances is useful in the case of high glucose concentration; the hypoglycaemic effect of the diet supplemented with inulin is mentioned in the literature ${ }^{27}$.

\section{Conclusions}

The analysis of the influence using different type of inulin shows that inulin extracted by optimized extractions has an effective positive influence on laboratory animals' metabolism.

Related to the extraction method, MHG, and optimization of the process, the optimal values for the parameters of microwave extraction in the gravitational field for which the efficiency is maximum $(72.98 \%)$ were obtained: temperature $=74.74^{\circ} \mathrm{C}$ and time $=15.55 \mathrm{~min}$.

By applying this method, we confirmed that the temperature plays a determining role for the extraction of inulin from Jerusalem artichoke, this being the parameter that determines the lysis of cell walls and membranes and the transfer of inulin from the solid phase to the liquid phase.

Following our study of the effects of inulin treatment obtained by extraction in 8 groups of 10 laboratory animals ( 4 group of WISTAR rats and 4 group of ALBINO SWISS), we confirmed the direct and indirect action of health improvement translated by indicators such as body weight.

\section{Author contributions}

M.D. was responsible for the obtaining of inulin, statistical analysis of the data, optimization of the extraction process, preparation of the 3 types of inulins used in testing on laboratory animals. N.B. was responsible for the development of experimental plan, statistical analysis of the extraction and purification method's parameters. C.E.D.P. was responsible for the procedures related to the administration of the inulins to laboratory animals, measurements and analysis of the effects and statistical analysis of the obtained data. All the authors have read and agreed to the published version of the manuscript.

\section{Conflict of Interest}

"The authors declare no conflict of interest regarding this article."

\section{Compliance with Ethics Requirements}

"The authors declare that all the procedures and experiments of this study respect the ethical standards in the Helsinki Declaration of 1975, as revised in 2008(5), as well as the national law."

\section{Acknowledgments}

"The study was supported by the Research Centre for the Study of Quality Food Products - HORTINVEST (University of Agronomic Sciences and Veterinary Medicine of Bucharest) and the Faculty of Pharmacy, "Carol Davila" University of Medicine and Pharmacy."

\section{References}

1. Raven JA. The role of vacuoles. New Phytologist. 1987;106(3):357-422.

2. Chi Z-M, Zhang T, Cao T-S, Liu X-Y, Cui W, Zhao C-H. Biotechnological potential of inulin for bioprocesses. Bioresource Technology. 2011;102(6):4295-4303.

3. Miremadi F, Shah NP. Applications of inulin and probiotics in health and nutrition. Journal of Food and Nutrition Research 2012;19(4):1337-1350.

4. Franck A, De Leenheer L. Inulin. Wiley-VCH Verlag GmbH \& Co. KGaA; 2005.

5. Stephen AM, Phillips GO, Williams PA. Food polysaccharides and their applications. Trends in Food Science $\mathbb{E}$ Technology, Elsevier Science Ltd. 1996; 7:207-208.

6. Yi H, Zhang L, Hua C, Sun K, Zhang L. Extraction and enzymatic hydrolysis of inulin from Jerusalem artichoke and their effects on textural and sensorial characteristics of yogurt. Food and Bioprocess Technology. 2010;3(2):315-319.

7. Van Loo J. Inulin-type fructans as prebiotics. Prebiotics: Development $\mathcal{E}$ Application. John Wiley \& Sons, Ltd; 2012:57-100

8. Chemat F, Vian M, Visinoni F. Microwave hydrodiffusion for isolation of natural products. European Patent Application. EP 1955749 A1. Bulletin 2008/33. Application number $07100935.1 ; 2008$. 
9. Mason JT, Chemat F, Vinatoru M. The extraction of natural products using ultrasound or microwaves. Current Organic Chemistry. 2010;15(2):237-247.

10. Coxam V. Inulin-type fructans and bone health: state of the art and perspectives in the management of osteoporosis. The British Journal of Nutrition. 2005;93(S1):S111-S123.

11. Van Den Heuvel EGHM, Muys T, Van Dokkum W, Schaafsma G. Oligofructose stimulates calcium absorption in adolescents. The American Journal of Clinical Nutrition. 1999;69(3):544-548.

12. Kaur N, Gupta AK. Applications of inulin and oligofructose in health and nutrition. Journal of Biosciences. 2002;27(7):703-714.

13. Coudray C, Bellanger J, Castiglia-Delavaud C, Rémésy C, Vermorel M, Rayssignuier Y. Effect of soluble or partly soluble dietary fibres supplementation on absorption and balance of calcium, magnesium, iron and zinc in healthy young men. European Journal of Clinical Nutrition. 1997;51(6):375-380.

14. Arrizón J, Urias-Silvas JE, Sandoval G, et al. Production and bioactivity of fructan-type oligosaccharides. Moreno FJ, Sanz Maria L, ed. Food Oligosaccharides: Production, Analysis and Bioactivity. John Wiley \& Sons, Ltd; 2014:184-199.

15. Boutron-Ruault M-C, Marteau P, Lavergne-Slove A, et al. Effects of a 3-mo consumption of short-chain fructo-oligosaccharides on parameters of colorectal carcinogenesis in patients with or without small or large colorectal adenomas. Nutrition and Cancer. 2005;53(2):160-168.

16. Verghese M, Walker LT, Shackelford L, Chawan CB. Inhibitory effects of nondigestible carbohydrates of different chain lengths on azoxymethane-induced aberrant crypt foci in Fisher 344 rats. Nutrition Research. 2005;25(9):859-868.

17. Taper HS, Roberfroid M. Influence of inulin and oligofructose on breast cancer and tumour growth. The Journal of Nutrition. 1999;129(7 Suppl):1488S-1491S.

18. Roller M, Femia A Pietro, Caderni G, Rechkemmer G, Watzl B. Intestinal immunity of rats with colon cancer is modulated by oligofructose-enriched inulin combined with Lactobacillus rhamnosus and Bifidobacterium lactis. British Journal of Nutrition. 2004;92(6):931-938.

19. Watzl B, Girrbach S, Roller M. Inulin, oligofructose and immunomodulation. The British Journal of Nutrition. 2005 Apr;93 Suppl 1:S49-55.

20. Stanley S, Wynne K, Bloom S. Gastrointestinal satiety signals III. Glucagon-like peptide 1, oxyntomodulin, peptide YY, and pancreatic polypeptide. American Journal of Physiology. Gastrointestinal and Liver Physiology. 2004;286(5):G693-G697.

21. Redondo-Cuenca A, Herrera-Vázquez SE, Condezo-Hoyos L, Gómez-Ordóñez E, Rupérez P. Inulin extraction from common inulin-containing plant sources. Industrial Crops and Products. 2021;170, 113726.

22. Ku Y, Jansen O, Oles CJ, Lazar EZ, Rader JI. Precipitation of inulins and oligoglucoses by ethanol and other solvents. Food Chemistry. 2003;81(1):125-132.

23. Saengkanuk A, Nuchadomrong S, Jogloy S, Patanothai A, Srijaranai S. A simplified spectrophotometric method for the determination of inulin in Jerusalem artichoke (Helianthus tuberosus L.) tubers. European Food Research and Technology. 2011;233(4):609-616.

24. Franck A, Levecke B. Inulin. Ullmann's Encyclopedia of Industrial Chemistry. Wiley-VCH Verlag GmbH \& Co. KGaA; 2000.

25. Williams CM. Effects of inulin on lipid parameters in humans. The Journal of Nutrition. 1999;129(7):1471S-1473S.

26. Pouyamanesh Z, Amoli MM, Yaghmaei P, Ebrahim-Habibi A. Effect of inulin supplementation in male mice fed with high fat diet on biochemical profile and $\alpha$-amylase gene expression. Tropical Journal of Pharmaceutical Research. 2016;15(6):1197-1203.

27. Zhang Q, Xiao X, Zheng J, et al. Influence of maternal inulin-type prebiotic intervention on glucose metabolism and gut microbiota in the offspring of C57BL mice. Frontiers in Endocrinology. 2019;10:675. 